\title{
RESEARCH IN THE FIELD OF ENTERPRISE MANAGEMENT
}

\author{
Mukhamadzhanov SHAKHRIYOR
}

Tashkent State University of Economics, Tashkent, Uzbekistan Corresponding author's e-mail: shaxri_7700@list.ru

\begin{abstract}
The need for a competitive enterprise to comply with the requirements of a market economy obliges it to constantly improve both technologically and organisationally. The basis of organisational innovation is the study of organisation management systems - activities aimed at the development and improvement of management in accordance with constantly changing external and internal conditions. Improving the management of modern dynamically developing enterprises, as socio-technical systems, requires the study of their properties, which is associated with solving the problem of performing research at a high scientific and methodological level. The article is devoted to the principles, methods and problems of these studies.
\end{abstract}

Keywords: Improvement, management, management systems, methods, problems, research.

\section{INTRODUCTION}

In the conditions of dynamism of modern production and social structure, management is in a state of constant development, which is currently impossible to implement without exploring the ways and possibilities of this development, without choosing alternative directions, without innovation (Kurpayanidi, 2019).

Management research is carried out in the daily activities of managers and personnel and in the work of specialised analytical groups, laboratories, departments.

A high level of development of enterprise management has been identified as a decisive factor in the success of enterprises. The success of enterprises is determined by a large number of factors, and therefore, management of enterprises is a complex task of assessing the activities of enterprise. The study of various areas of activity of modern enterprises is primarily the collection and analysis of data that determine the situation and development trends of an enterprise at the present stage (Kurpayanidi \& Mamurov, 2019).

\section{RESEARCH METHODS}

For the development of methods and improvement of management and activities of companies, is important:

- to study the potential of a company in the area of management; to perform an analysis of trends in this sector of economy; 
- to identify and assess the driving forces of development;

- to perform a comparative assessment of the results of economic activities taking into account development prospects.

Research experience shows that the following factors affect the quality of research: availability of highly qualified specialists and experience in conducting research; in-depth knowledge of the features of the product manufacturing technology; objectivity in research; availability of special standardised research programs; the relevance of research results for the top management of companies.

Based on an analysis of the available literature and personal experience in production, including innovative activities related to the introduction of new methods of labour organisation and analysis of the effectiveness of individual management decisions, independent research in the field of management of modern enterprises (for example, General Motors Uzbekistan JSC as the most technologically advanced domestic industrial enterprise), it can be argued that in order for research to be effective:

- it must be systematic;

- a scientific approach based on objectivity and accuracy must be observed;

- collection, recording and analysis of data should be carried out at the lowest level of government.

\section{LITERATURE REVIEW}

Under these conditions, it is necessary to move from processing of already existing secondary information, i.e., data collected at the enterprise for purposes other than the problem being solved at the moment (desk research method), to field research - the collection and processing of specially collected data for specific analysis. In the best, ideal case, field research involves the participation of the researcher in obtaining primary information by accumulating his own data obtained by strictly scientific methods and on the basis of his own observations and surveys of participants in the management and organisation of technological processes.

For research in the field of enterprise management, especially concerning the problems of the development of management tools and methods, techniques and technologies, and, especially, personnel, the most developed and widely used method of obtaining the necessary information is the survey of the circle of people directly related to the problem under study, which allows us to identify the essence of processes through the personal attitude of each.

At present, one of the most important indicators of the development potential of an enterprise is the activity of personnel in improving the operation of the enterprise through improving technological processes, increasing labour productivity and product quality, reducing its cost in the framework of rationalization activities and the work of "quality circles".

According to the researchers of modern management problems Imai (1986), Stephens (2004), Womack \& Jones (2015) and others, activities to improve the work of an enterprise are an important feature of modern production and an integral part of modern production systems, such as Quality System Management, TQM (Total Quality Management), Lean Production or Continuous Improvement. These systems have been introduced and successfully applied at the enterprises of 
Uzavtosanoat JSC, the most technologically advanced industry - the modern automotive industry (Teshabaev, 2017).

At the same time, further improvement of the industry is required. According to the Decree of the President of the Republic of Uzbekistan dated 1 June 2017 No. PP-3028 "On Measures for Accelerated Development and Further Improvement of Management of the Automotive Industry in 2017-2021" (2017), by 2021 the enterprises of Uzavtosanoat JSC should increase the production of commercial products by three times to reduce the share of imports in production to $12.5 \%$ and to increase the number of people employed in the industry to $120 \%$. The Decree provides for the development of 51 new projects, incl. 7 new car models, technical re-equipment and modernization of 9 industry enterprises, 35 projects for the localization of raw materials (including steel for the automotive industry) and auto components.

In our opinion, achieving the tasks set by the Decree requires a radical improvement in the organisation of the activities of enterprises. First of all, this concerns problems of sectoral importance, such as the development of infrastructure, improvement of management and, above all, the quality management system, training of qualified personnel and others.

\section{RESULTS AND DISCUSSION}

The present section considers the features, methods and problems of improving quality management systems (QMS) at modern enterprises. Quality management system, according to ISO 9000, is the most important factor for the economy of any country. According to international studies, by introducing ISO 9001 standards and improving the quality of goods and services, increasing confidence in the quality of domestic products, meeting the expectations and requirements of consumers, an increase in $1 \%$ of gross domestic product is achieved, i.e., 864 USD per consumer, and a decrease in inflation by $0.4 \%$.

Certification for ISO 9000 requirements and the creation of integrated quality management systems of the latest generation are expensive. The results and efficiency of the systems should ensure their high return. Quality activities are especially important for the industry of Uzbekistan, which is undergoing a stage of modernization and development of new types of production. Large enterprises of various sectors of the economy are actively implementing the most advanced strategies, including management methods, i.e., quality management according to the new version of the international standard ISO 9001: 2015 at Uzbekistan Railways JSC, Navoiyazot JSC and others.

As of 1 December 2019, 10694 QMS systems were included in the State Register of Certified Quality Management Systems of the Republic of Uzbekistan 10427 enterprises and organisations of the republic were certified for compliance with the requirements of international standards, including ISO 90019923, ISO 14001-99, OHSAS 18001-143, ISO 50001-69, ISO / TS 16949 (quality assurance of supplied parts in the automotive industry - 43 and GMP - 22). Quality management systems of domestic enterprises are mainly based on international standards ISO 9000, although there are other models of quality management 
systems (UZSTANDARD” agency, n. d.).

However, despite high costs, attention and support of government authorities, and the management of the companies themselves, the quality management systems often do not justify the hopes placed on them. First of all, this refers to the achievement of the main, system-forming goal of standardisation - to ensure high, appropriate quality of products and services and the development of the enterprise and the management system.

According to the overwhelming majority of the respondents (up to $80 \%$ ) specialists and production managers, quality specialists and quality systems specialists at the enterprises of the automotive industry of Uzavtosanoat JSC, the effectiveness of quality management systems does not meet expectations, as well as the activities of departments and groups of quality management systems are weakly correlated with quality indicators.

There are many reasons for this situation, the main ones being:

- organisational - the creation of structural subdivisions of quality management systems, separate from the structural subdivisions of quality, facilitates the processes of creation and certification, development of quality management systems, but efficiency in quality assurance becomes weak, due to the creation of QMS as a self-sufficient goal;

- administrative - weak coordination of QMS performance indicators with other plant-wide ones in planning and control, poor training of employees of QMS divisions in terms of administration of production processes and a lack of authority, which play the responsible role for the quality of final production;

- insufficient level of development of enterprise management-determined, for example, by the number of invited experts to solve highly specialised problems, incl. problems of ensuring the quality of products and processes.

Most of these problems are formalized, i.e., the nature of the problem, its causes and drivers, development trends and solutions are clear. In view of the complexity of these problems, their solution requires comprehensive research at a high scientific and methodological level.

The most important task of quality management and of modern enterprise management is the organisation and motivation of the creative work of personnel to improve the quality of products and processes.

In studies on Japanese management, it is pointed out that Japanese companies owe much of their success in ensuring product quality to the creative attitude of their employees. For example, at Japanese car companies, each employee annually provides an average of 61.6 proposals for improving processes, while this figure for their European colleagues is 0.4 (Shingo \& Bodek, 2019).

Therefore, the study, adaptation and development of methods for involving employees in product quality management andgeneral development of a company, the formation of a creative attitude of employees to their work have become the primary goals and objectives of European and American researchers and quality management practitioners.

Significant resources were allocated to the study of the methods and tools of quality management of Japanese enterprises, and naturally, great success was 
achieved. For example, the indicators for submitting proposals for improvements were 4.2 for the USA and 1.9 for European car factories (Carnerud, 2018; Teece, 2018).

The involvement of employees in improving the quality of products and processes, the expansion of their technical creativity are recognised as very important at the enterprises of Uzavtosanoat, primarily at UzAuto Motors JSC, SamAvto LLC and JV MAN Auto-Uzbekistan LLC.

At UzAuto Motors JSC, following the pattern of foreign partners, since 2000, a system of proposals for improving production has been deployed, in many ways similar to innovation. During this period, the submission of rationalization proposals increased from 402 in 2000 to 12183 in 2019; the submission of rationalization proposals per employee increased from 0.12 to 2.11 . The implementation rate (the ratio of implemented and submitted rationalization proposals) over these years has grown from $35.1 \%$ to $66 \%$ and the participation of employees in rationalization (engagement rate) has increased from $3 \%$ to $82.7 \%$.

According to the indicators of submitting rationalization proposals per employee and their implementation, UzAuto Motors JSC reached the indicators of European automobile companies, and the involvement of employees in rationalization activities turned out to be $18 \%$ higher than the average European indicators. Savings from the introduction of rationalization proposals already in 2017 amounted to 678 thousand USD, and for the proposals submitted in 2018, the economic effect exceeded more than 1 million USD clearly showing the success in innovation.

However, the further history of the rationalization movement and, in general, the innovative activity in the company are characterised by stagnation, which is expressed both by the indicators of the submission of rationalization proposals at the work sites and places, and by the curtailment of some innovative programmes. A detailed analysis of innovation activity allows us to talk about problems in the development of innovation - formalism and administration, a large number of small, for the sake of a tick, proposals, the low value of most proposals.

To assess the state and identify ways to improve innovation, surveys were conducted among the participants in the innovation movement to identify real problems in the development of employee innovation. The following factors of rationalization activity were studied:

- motives for participation (striving to improve working conditions and remuneration);

- driving forces (initiative, innovation and management requirements);

- systemic factors (industrial and managerial culture, industrial climate, support and obstacles).

For the survey, a questionnaire ( 25 questions) was used, according to which the respondents assessed 10 factors of motives, driving forces, support or obstacles to rationalization activities.

Each question was evaluated from 1 to 5 points. 154 employees were interviewed - organisers of the rationalization movement and the best innovators in the rank of worker (19 people), skilled worker ( 27 people), foreman (48 people), engineer (15 people), assistant manager (30 people), manager (13 people) and 
assistant general manager (12 people).

The main purpose of the survey was to establish a relationship between the following factors:

- the level of development of employees and their activity;

- the development of the supply system and the performance of employees;

- material and moral motivation;

- administrative influence;

- quality of proposals.

Based on the results of the survey, reearcher's own observations and expert assessment, the following was established:

- the presence of a direct connection between the number of submitted rationalization proposals and administrative influence at the divisions (implementation of the plan for submitting rationalization proposals);

- the presence of feedback between the density of registration of proposals for a calendar period and indicators of the class of the submitted rationalization proposals;

- a direct link between the qualifications of the author of the proposal and the economic effect of the submitted proposal;

- the absence of stable correlations between 10 groups of indicators, which is explained both by the imperfection of the survey and questionnaire method itself, and by the inadequate assessment of the groups of indicators by the survey participants.

To identify the drivers of innovation and the motives of technical creativity at a modern industrial enterprise, it is necessary to continue research in the direction of:

- increasing the sample by expanding the circle of respondents and including employees who are not involved in innovation;

- improving the questionnaire;

- conducting panel surveys, i.e., surveys of specially selected and qualified persons, at regular intervals to track the dynamics of processes.

In general, we can conclude that the practical preparation and implementation of surveys at enterprises should have a strictly scientific approach to solving the problem under study and developing a proper methodological base.

The development strategy of the enterprise, based on the release of personal initiative, presupposes the strengthening of the role of advanced, innovative management in ensuring favourable economic conditions.

It is necessary to solve the main issue of employee management: to whom, how, for what and how much to pay. If you pay according to work, then you need to consider:

- past labour (merits of the past period);

- current performance (results, effectiveness of the current period);

- future prospects (building the employee's potential for the future);

- that in a modern enterprise, it is mainly hourly wages, i.e., labor is a process of joint activity (a measure of labor does not have a separate value; it cannot be weighed or measured separately from the labor of other workers).

Any indicators of this process, in particular, standards, are conditional and 
abstract, payment should depend on the team and value added departments created by joint work, for which it is necessary to introduce KPIs (Key Performance Indicators).

It should be noted that personnel management in terms of the development of initiative and creativity is very specific, since the more restrictions such a poorly organised system has, the more it requires resources and energy to maintain its existence. Therefore, it develops in a more difficult and slower way than a system without unnecessary restrictions.

Management is a type of human activity that has general and specific features. Common features reflect the stages of development and the level of scientific and technological progress. Specific features reflect national characteristics - culture, primarily labour and production, the level of socio-economic relations, which give an understanding of the existence of the American, Japanese, and now domestic management models (Khamidulin, 2015).

In the conditions of the development of a market economy, domestic management is distinguished by:

- extremely high speed of socio-economic processes that determine the business environment of management;

- a set of factors hampering the strengthening of scientific management in Uzbekistan;

- lack of objective assessments of the activities of managers, rotation of managers within organisations and schools of the reserve of leading personnel;

- low level of management accounting and analysis of the efficiency of enterprises and departments (Abdullaev \& Kurpyanidi, 2018; Margianti et al., 2016; Tairov, 2016).

In its most general form, the subject of research in modern management is problems as real contradictions that need to be resolved - the contradiction of management strategy and tactics, market conditions and firm capabilities, personnel qualifications and needs for innovation etc.

Research methodology assumes the purpose of research as a choice of problems and approaches - starting positions and starting points from which the research begins and which determine its focus in relation to the goal.

The approaches can be aspectual, systemic and conceptual.

The aspect approach represents the choice of one facet of the problem on the basis of relevance, or the availability of resources allocated for research. For example, the problem of personnel development can have an economic aspect, socio-psychological, educational etc.

The systems approach reflects a higher level of research methodology. It requires the maximum possible consideration of all aspects of the problem in their relationship and integrity, highlighting the main and essential ones, determining the nature of the relationship among aspects, properties and characteristics.

The conceptual approach assumes a preliminary development of the research concept, i.e., a set of key provisions that determine the focus, architectonics and continuity of the research.

Approaches can also be empirical, pragmatic, and scientific. If they mainly rely on 
experience, they are empirical; if they are based on the tasks of obtaining the nearest result, approaches are pragmatic. The most effective is the scientific approach, which is characterised by the scientific setting of research objectives and the use of the scientific apparatus in its conduct (Akhmetshin et al., 2017; Yoshida \& Takano, 2018).

The research methodology should also include the identification and formulation of benchmarks and constraints. They allow you to conduct research more consistently and purposefully. Benchmarks can be flexible and rigid, and restrictions are explicit or implicit (Foster \& Swenson, 1997).

\section{CONCLUSION}

It can be concluded that management studies, including quality management, require extensive, thorough and practical training. Selection of reliable sources of information, methods of their interpretation and processing should have a strictly scientific approach to solving the problem under study and due methodological base.

The main role in methodology is played by research methods, which can be divided into three groups: formal-logical, general scientific and specific. Formallogical are the methods of human intellectual activity that form the basis of management research. General scientific methods reflect the scientific apparatus of research, which determines the effectiveness of any type. Specific methods reflect the specifics of management activities.

\section{REFERENCES}

Abdullaev, A. M., \& Kurpyanidi, K. I. (2018). To the Problem of Classification of Institutional Conditions Determining Enterprise Structure in Uzbekistan. Scientific-Technical Journal, 22(1), 101-106.

Akhmetshin, E., Vasilev, V. L., Bakhvalov, S. I., Prikhod'ko, A. N., \& Kazakov, A. V. (2017). Internal Control in the System of Innovation Management in the Modern Business Environment. International Journal of Economic Research, 14(15), 409-416.

Carnerud, D., Jaca, C., \& Bäckström, I. (2018). Kaizen and Continuous Improvement - Trends and Patterns Over 30 Years. The TQM Journal, 30(4), 371-390. https://doi.org/10.1108/TQM-032018-0037

Collected Legislation of the Republic of Uzbekistan. (2017). On measures to further improve management and accelerate development of the automotive industry for 2017-2021. Decree of the President of the Republic of Uzbekistan no. PP-3028 dated June 1, 2017. No. 23, Art. 454.

Foster, G., \& Swenson, D. W. (1997). Measuring the Success of Activity-Based Cost Management and Its Determinants. Journal of management accounting research, 9, 109-142.

Imai, M. (1986). Kaizen: The Key to Japan's Competitive Success. McGraw-Hill.

Khamidulin, M. B. (2015). Basic Directions of Improving Corporate Governance in the Republic of Uzbekistan. International Academic Bulletin, no. 6, pp. 56-57.

Kurpayanidi, K. I. (2019). Theoretical Basis of Management of Innovative Activity of Industrial Corporation. ISJ Theoretical \& Applied Science, 01(69), 7-14. https://doi.org/10.15863/tas.2019.01.69.3

Kurpayanidi, K., \& Mamurov, D. (2019). Features of the Support of the Innovative Activity: Foreign Experience and Practice for Uzbekistan. Bulletin of Science and Practice, 5(11), 255-261. https://doi.org/10.33619/2414-2948/48/29

Margianti, E. S., Ikramov, M. A., \& Abdullaev, A. M. (2016). Entrepreneurship in Uzbekistan: Trends, Competitiveness, Efficiency. Gunadarma Publisher. 
Shingo, S., \& Bodek, N. (2019). A Study of the Toyota Production System: From an Industrial Engineering Viewpoint. Routledge. https://doi.org/10.4324/9781315136509

Stephens, K. S. (2004). Juran, Quality, and a Century of Improvement: The Best on Quality Book Series of the International Academy for Quality, Volume 15. Quality Press.

Tairov, S. (2016). Efficiency of the Quality Management System in Joint-Stock Companies of Uzbekistan // Modern technologies in science and education-STNO-2017. pp. 130-132.

Teece, D. J. (2018). Tesla and the Reshaping of the Auto Industry. Management and Organization Review, 14(3), 501-512. https://doi.org/10.1017/mor.2018.33

Teshabaev, A. E. (2017). Improving Management at Modern Enterprises. Tashkent.

UZSTANDARD” agency. (n. d.). State Register of Certified Quality Systems. Retrieved from https://www.standart.uz/ru/page/view?id=43 [Accessed on 20 September 2020].

Womack, J. P., \& Jones, D. T. (2015). Lean Solutions: How Companies and Customers Can Create Value and Wealth Together. Simon and Schuster.

Yoshida, K., \& Takano, K. I. (2018). Research on Organizational Climate Factors Contribute to Improving Performance in Modern Companies. Journal of Japan Industrial Management Association, 69(1), 1-20. https://doi.org/10.11221/jima.69.1

\section{AUTHOR'S SHORT BIOGRAPHY}

Mukhamadzhanov Shakhriyor is the Head of the Department of the "El-yurt umidi" Foundation under the Cabinet of Ministers of the Republic of Uzbekistan. The Foundation is engaged in training personnel abroad in prestigious areas at the expense of the state. Mukhamadzhanov has been conducting research in the field of management and production for the past three years. He has published over ten theses and articles. He is self-interested in corporate governance and is going to become a $\mathrm{PhD}$ in this field.

E-mail: shaxri7700@list.ru

ORCID ID: https://orcid.org/0000-0001-7392-1730 